\title{
Gymnasts' Special Quickness-Force Abilities and the Indicators of Jump from a Springboard
}

DOI: $10.2478 / v 10131-0014-9$

Authors' Contribution:

A - Study Design

B - Data Collection

C - Statistical Analysis

D - Data Interpretation

E - Manuscript Preparation

F - Literature Search

$\mathrm{G}$ - Funds Collection

\author{
Adam Koperski ${ }^{(\mathrm{A}, \mathrm{B}, \mathrm{C}, \mathrm{F})}$, Andrzej Kochanowicz ${ }^{(\mathrm{D}, \mathrm{E}, \mathrm{F})}$, \\ Czesław Słodkowski ${ }^{(\mathrm{D}, \mathrm{E})}$
}

Jedrzej Sniadecki Academy of Physical Education and Sport in Gdansk, Poland

Key words: artistic gymnastics, quickness and force abilities, take-off power, vault.

Background:

Abstract

Material/Methods: The tests were made on gymnasts, aged 15-18 years, from the Academic Sports

The aim of this research is to find a relation between one's special quickness-force abilities, recorded in laboratory conditions, and physical values, revealed during a gymnastic jump in a real sports contest. Association (AZS) in Gdansk. The gymnasts were a selected group of 8 people who had already practised sport for 9-12 years as contestants. The project was carried out in the Physical Effort Laboratory at the Academy of Physical Education and Sport (AWFiS) in Gdansk, using of the Kistler tensometric platform to measure and analyse the ground reaction forces. The strength of leg muscles and pelvic girdle were checked. The measurements of quickness and force abilities of sportsmen were based on the assessment of power of their take-off and the time in which they contacted the ground. The results were compared with the result analysis of jumps achieved by the contestants in the Individual Polish Championships (Ilawa 2005). The measurement of the mechanical quantities during the take-off at the springboard was done using the photogrammetric method.

Results: The statistically highest and important correlation between the results of gymnasts in the quantity of the take-off power, checked on the tensometric platform and at the springboard was with the value being $r=0.916$ for $p \leq 0.05$. A crucial correlation was also observed for the time of the contestant's contact with the ground in laboratory tests and the same parameter measured during the contestant's taking off the springboard $(r=0.668)$.

Conclusions: The analysis of test results reveals a strict correlation between the level of one's abilities in quickness and force in laboratory conditions and physical values revealed during the take-off from a springboard in an actual contest.

The measurement of the quickness-force abilities (the power of take-off) in laboratory conditions can be used as the measurement of the sportsmen's preparation for the gymnastic jump.

Word count: 1144

Tables: 3

Received: June 2010

Figures: -

Accepted: Semptember 2010

References: 20

Published: December 2010

Address for correspondence:

Mgr Adam Koperski

Academy of Physical Education and Sport, Department of Gymnastics, 80-336 Gdańsk, Poland, ul. K. Górskiego 1

Phone: +4858 554-73-21, e-mail: koperskia@wp.pl 


\section{Introduction}

The demonstration of the power of muscles, being one of the most important motor skills in artistic gymnastics, requires multi-directional research which will help to locate important points in the training process of gymnasts at various stages of their advancement $[1,2,3,4,5]$. Because of the specificity of this sport discipline, determination of one's quickness and force is a rich source of information on one's potential and it is an important indicator of the effectiveness of his/her training process $[6,7,8,9,10,11]$. There is a close relation between one's quickness and force abilities and the way in which one performs a given motion task, receiving a specific result in sport $[12,13,14,15,16]$.

In artistic gymnastic, the character of muscle work depends on the requirements in particular contests in all-around gymnastics. A gymnastic vault is characterised by a short time of performance with the optimum use of one's quickness-force as well as co-ordination skills in every phase of the jump $[17,18]$.

The aim of this research is to find a relation between one's special quickness-force abilities, recorded in laboratory conditions, and physical values, revealed during a gymnastic jump in a real sports contest.

\section{Material and method}

The tests were made on gymnasts, aged 15-18 years, from the Academic Sports Association (AZS) in Gdansk. The gymnasts were a selected group of 8 people who had already practised sport for 9-12 years as contestants. The entire project was carried out in the Physical Effort Laboratory at the Academy of Physical Education and Sport (AWFiS) in Gdansk, using of the Kistler tensometric platform to measure and analyse the ground reaction forces. The following data were checked: the strength of leg muscles and pelvic girdle. The measurements of quickness and force abilities of sportsmen were based on the assessment of power of their take-off and the time in which they contacted the ground. The results were compared with the result analysis of jumps achieved by the contestants in the Individual Polish Championships (lława 2005). The measurement of the mechanical quantities during the take-off at the springboard was done using the photogrammetric method. Next, the collected material was analysed statistically using the Excel and Statistica 7.0 PL software.

\section{Results}

The highest power was achieved in jumps on the tensometric pathway by Ł.M. (65.0), and the lowest one by S.P. $(45.2 \mathrm{~W})$. The mean result of the group was $56.2 \mathrm{~W}$, against relatively low dissipation of the results (standard deviation -6.5). The shortest time of contact with the ground was obtained by gymnast W.A. $(0.117 \mathrm{~s})$, and the longest one by J.P. $(0.17 \mathrm{~s})$. The mean time of contact with the ground in the research group was $0.15 \mathrm{~s}$, with standard deviation at 0.02 (Tab. 1).

The extreme results recorded during the take-off at the springboard at the Polish Championships (lława 2005) achieved by the same gymnasts as in the laboratory condition were Ł.M. $4987 \mathrm{~W}$ and S.P. $3228 \mathrm{~W}$ respectively, while the shortest time of contact with the sprongboard, $0.12 \mathrm{~s}$, was obtained by gymnasts W.A. and R.B. and the longest one, $0.15 \mathrm{~s}$, by J.P. and R.M. $-0.15 \mathrm{~s}$. The mean contact with the springboard of the group was $0.13 \mathrm{~s}$, and the standard deviation was 0.01 (Tab. 2).

The statistically highest and important correlation between the results of gymnasts in the quantity of the take-off power, checked on the tensometric platform and at the springboard was with the value being $r=0.916$ for $p \leq 0.05$ (Tab. 3). A crucial correlation was also observed for the time of the contestant's contact with the ground in laboratory tests and the same parameter measured during the contestant's taking off the springboard $(r=0.668)$. 
Tab. 1. The results of gymnasts' take-off, considering the parameter of force and the contact time with the ground

\begin{tabular}{ccc}
\hline Gymnasts' initials & Force of take-off [W] & Contact time with the ground [s] \\
\hline D. M. & 56.2 & 0.131 \\
J. P. & 49.7 & $\mathbf{0 . 1 7 0}$ \\
W. A & 57.7 & $\mathbf{0 . 1 1 7}$ \\
R. M & 62.2 & 0.166 \\
Ł. M & 65.0 & 0.152 \\
T. K. & 59.3 & 0.164 \\
R. B & 54.0 & 0.154 \\
S. P. & $\mathbf{4 5 . 2}$ & 0.147 \\
Mean results & 56.16 & 0.150 \\
Standard deviation & 6.47 & 0.02 \\
\hline
\end{tabular}

Tab. 2. Physical values of the sportsmen's take-off on a springboard

\begin{tabular}{ccc}
\hline Gymnasts' initials & Force of take-off [W] & $\begin{array}{c}\text { Contact time with the } \\
\text { springboard [s] }\end{array}$ \\
\hline D. M. & 4774 & 0.13 \\
J. P. & 3745 & $\mathbf{0 . 1 5}$ \\
W. A & 3984 & $\mathbf{0 . 1 2}$ \\
R. M & 4522 & $\mathbf{0 . 1 5}$ \\
L. M & 4987 & 0.13 \\
T. K. & 4310 & 0.13 \\
R. B & 3960 & $\mathbf{0 . 1 2}$ \\
S. P. & 3228 & 0.14 \\
Mean results & 4189 & 0.13 \\
Standard deviation & 576.7 & 0.01 \\
\hline
\end{tabular}

Tab. 3. The correlation between laboratory results and physical values during the take-off from the springboard

\begin{tabular}{|c|c|c|c|c|c|}
\hline \multirow{2}{*}{$\begin{array}{l}\text { Kind of } \\
\text { research }\end{array}$} & \multirow[b]{2}{*}{ Parameters } & \multicolumn{2}{|c|}{ Laboratory results } & \multicolumn{2}{|c|}{ Take-off from the springboard } \\
\hline & & $\begin{array}{c}\text { Force of take- } \\
\text { off }\end{array}$ & $\begin{array}{l}\text { Contact time } \\
\text { with the } \\
\text { ground }\end{array}$ & $\begin{array}{c}\text { Force of take- } \\
\text { off }\end{array}$ & $\begin{array}{l}\text { Contact time } \\
\text { with the } \\
\text { springboard }\end{array}$ \\
\hline \multirow{2}{*}{ 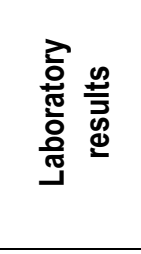 } & $\begin{array}{c}\text { Force of take- } \\
\text { off }\end{array}$ & $x$ & & & \\
\hline & $\begin{array}{l}\text { Contact time } \\
\text { with the } \\
\text { ground }\end{array}$ & -0.115 & $x$ & & \\
\hline \multirow{2}{*}{ 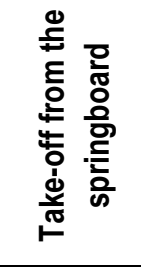 } & $\begin{array}{c}\text { Force of take- } \\
\text { off }\end{array}$ & 0.916 & -0.124 & $x$ & \\
\hline & $\begin{array}{l}\text { Contact time } \\
\text { with the } \\
\text { springboard }\end{array}$ & -0.241 & 0.668 & -0.205 & $x$ \\
\hline
\end{tabular}




\section{Discussion}

In special research attention was devoted to the relation between motor skills and technical preparation in the chosen all-around gymnastics [19,20]. In the opinion of Gaverdovskij and Smolevskij [1] quickness-force possibilities greatly decide about the quality and the effectiveness of learning gymnastic exercises. In the research conducted by Szot et al. [14] attention was paid to a high relation between the power of take-off from the springboard and from the gymnastic table with the height of the performed vaults. A. Kochanowicz et al. [17] define that the height level of technical preparation in gymnastic vaults depends, among others, on individual quickness-force abilities recorded in laboratory conditions.

The presented research has defined the level of quickness-force abilities of sportsmen and indicated the correlation between the take-off in laboratory conditions and the results during actual contests. The parameters of muscle work of the leg and hip area are strictly correlated with the power of the take-off on a springboard.

Similarly, a high interdependence was noted in laboratory tests, testing the time of a sportsman's contact with the ground. The above information can be used as a starting point for further search for more effective monitoring during training. Short laboratory tests of quicknessforce abilities on a tensometric platform can broaden the scope of special training of sportsmen, preparing them to the vault on a gymnastic table. However, in this case, all remaining aspects must be taken into account, including a recording and analysis of the training load, the level of one's advancement in sport practice and other components of contestants' training process.

\section{Conclusions}

1. The analysis of test results reveals a strict correlation between the level of one's abilities in quickness and force in laboratory conditions and physical values revealed during the takeoff from a springboard in an actual contest.

2. The measurement of the quickness-force abilities (the power of take-off) in laboratory conditions can be used as the measurement of the sportsmen's preparation for the gymnastic jump.

\section{References}

1. Gaverdovskij JK, Smolevskij VM. Sportivnaya gimnastika [Sports gymnastics]. Moskva: FiS; 1979 [in Russian].

2. Karniewicz J, Kochanowicz K, Sawczyn S. Technika wykonania i metodyka nauczania gimnastycznych skoków przez konia [Technique and methodology of teaching gymnastic horse vault]. Gdańsk: AWF; 1993 [in Polish].

3. Kochanowicz K. Kompleksowa kontrola w gimnastyce sportowej [The comprehensive control in artistic gymnastics]. Gdańsk: AWF; 1998 [in Polish].

4. Sawczyn S, Kruczkowski D. Analiza porównawcza gimnastycznych programów szkoleniowych wybranych krajów świata na etapie przygotowania początkowego (8-12 lat) [A comparative analysis of training programmes applied in the chosen countries at the praparation stage]. In: Sydney $2000-$ efektywność programów szkolenia w sporcie. Międzynarodowa Konferencja Naukowo-Metodyczna, Spała 24-26 listopada 1997 [Syndey 2000 - efficiency of training programmes in sport. International Scientific-Methodological Conference Spała 24-26 Nov. 1997]. Warszawa: PTNKF; 1997: 40 [in Polish].

5. Zasada M. Przygotowanie fizyczne i funkcjonalne gimnastyków w wieloletnim procesie treningowym [Physical and functional preparation of gymnasts in a many-year training process]. Bydgoszcz: Uniwersytet Kazimierza Wielkiego; 2007 [in Polish].

6. Arkayev LYa. Integralnaya podgotovka gimnastov (na primiere sbornoy komandy strany) [Integrated preapration of gymnasts (on a aexample of a state reprezentation]. PhD Dissertation. Moskva: IKF; 1994 [in Russian].

7. Cools AM, Geerooms E, Van den Berghe DFM, Cambier DC, Witvrouw EE. Isokinetic scapular muscle performance in young elite gymnasts. J Athl Train 2007; Oct-Dec;2(4):458-463.

8. Koperski A, Słodkowski C. Rozwój zdolności siłowych jako wskaźnik kształtowania mistrzostwa sportowego gimnastyków na etapie specjalnym [Development of strength skills as a coefficient of creating sports championship at a special stage]. In: Umiastowska D, editor. Aktywność ruchowa ludzi 
w różnym wieku. t. 12 [Physical activity in elderly persons]. Szczecin: Wydawnictwo Promocyjne „Albatros”; 2008: 244-250 [in Polish].

9. Kraemer WJ, Fleck SJ. Strength training for young athletes. Champaigne: Human Kinetics; 1993.

10. Raczek J. Teoria motoryczności (antropomotoryka) w systemie nauk o kulturze fizycznej [A motor theory (anthropomotorics) in sciences on physical culture]. Antropomotoryka 1989;1:5-18 [in Polish].

11. Sawczyn S. Podstawy kontroli obciążeń treningowych w gimnastyce sportowej [Basics of training loads control in sports gymnastics]. Gdańsk: AWFiS; 2008 [in Polish].

12. Kochanowicz K, Sawczyn S, Kruczkowski D, Mikołajek P. Dynamika rozwoju sprawności fizycznej gimnastyków na różnych szczeblach zaawansowania sportowego [Dynamics of physical fitness development at various stages of sports advancement]. Trening 1997;2:147-152 [in Polish].

13. Staszkiewicz R, Ozimek M. Związek wyników sportowych i parametrów biomechanicznych charakteryzujących sprinterów wysokiej klasy. [Relation between sports results and biomechanical parameters]. In: Sozański H, Perkowski K, Śledziewski D, editor. Trening sportowy na przełomie wieków [Sports training at the turn of centuries]. Warszawa: AWF; 2002: 138-142 [in Polish].

14. Szot Z, Koperski A, Dargiewicz R, Blanik L. Parameters of horse vault technique at the champion's level In: World Congress of Performance Analysis of Sport VIII. Magdeburg: the Otto von Guericke University; 2008: 223.

15. Ruchlewicz T, Staszkiewicz R. W czym tkwi tajemnica dalekich skoków Małysza? [What is the secret of Małysz'es jumps?]. Sport Wyczynowy 2001;9-10:13-21 [in Polish].

16. Zaporozhanov VA, Platonov VN. Prognozovanije i modielirovanije v sportie. Teoria sporta [Forecasting and modelling in sport. Theory of sport]. Kiev: Visha Shkola; 1985: 350-371 [in Russian].

17. Kochanowicz A, Kochanowicz K, Sawczyn S. Special fitness and the effectiveness of technical preparation in gymnastic vault event in athletes at the directed stage. Baltic Journal of Health and Physical Activity 2009;1:65-72.

18. Levit A, Dargiewicz R, Dancewicz T, Kruczkowski D, Mikołajek P. Ocena sędziowska wobec kinematycznej oceny wybranych zawodników zakwalifikowanych do finału podczas skoku na ME w gimnastyce sportowej [Judges' assessment and the kinematic assessment of selected athletes qualified for the vault finals in the European Championship in artistic gymnastics]. Trening 2000;2-3:271273 [in Polish].

19. Kochanowicz A. Sprawność fizyczna a efektywność przygotowania technicznego gimnastyków na etapie ukierunkowanym. Rozprawa doktorska [Physical fitness vs. efficiency of technical preparation at the directed stage. PhD Dissertation]. Gdańsk: AWFiS; 2010.

20. Menkhin JuV. Fizicheskaya podgotovka v gimnastikie [Physical preparation in gymnastics]. Moskva: FiS; 1989 [in Russian]. 